\title{
Soil Depth and Climatic Effects on Desert Vegetation Dynamics
}

\author{
Godfrey Khumalo, ${ }^{1}$ Jerry Holechek, ${ }^{2}$ Milt Thomas, ${ }^{3}$ and Francisco Molinar ${ }^{4}$
}

Authors are ${ }^{1}$ Research Assistant, ${ }^{2}$ Professor, and ${ }^{3}$ Associate Professor, Department of Animal and Range Sciences, New Mexico State University, Las Cruces, NM 88003, USA; and ${ }^{4}$ Range Conservationist, US Department of Agriculture-Natural Resources Conservation Service, El Paso, TX 79821 , USA.

\begin{abstract}
Soil depth effects on honey mesquite (Prosopis glandulosa Torr) cover and density and perennial grass standing crop were evaluated over an 11-yr period (1995-2005) on two lightly stocked and two conservatively stocked pastures on the Chihuahuan Desert Rangeland Research Center in south-central New Mexico. These four adjoining pastures have similar size, vegetation, and soils. Soils in these study pastures are primarily light sandy loams varying from a few centimeters to $1 \mathrm{~m}$ or more in depth underlain by a calcium carbonate layer. Deep soils had lower perennial grass standing crop and higher honey mesquite cover and density than did shallow soils at both the beginning (1995-1997) and ending (2003-2005) periods of study. Average perennial grass standing crop across the four study pastures dropped 82\% between 1995-1997 and 2003-2005 because of drought during the last $5 \mathrm{yr}$ of study. Honey mesquite canopy cover and perennial grass standing crop did not differ between light and conservative grazing treatments at the beginning or end of our study. Honey mesquite canopy cover did not change from 1995-1997 to 2003-2005 but honey mesquite density was higher in 2003-2005 than in 1995-1997. Our study shows that both soil depth and climatic fluctuations have a major influence on vegetation dynamics in desert and semiarid areas.
\end{abstract}

\section{Resumen}

Los efectos de la profundidad del suelo en la cobertura y densidad de mezquite (Prosopis glandulosa Torr) se evaluaron por un periodo de 11 años (1995-2005), lo mismo que la productividad de gramíneas perennes. Se utilizaron dos potreros con carga ligera y dos potreros con carga conservadora en el Centro de Investigaciones de pastizales del desierto Chihuahuense, localizado en la parte sur-centro de Nuevo México. Los 4 potreros colindaban y tenían el mismo tamaño, y vegetación y suelos similares. La composición de los suelos en los potreros era areno-arcillosa ligera con mezclas de caliche, con una variación en la profundidad de pocos centímetros a un metro. En los suelos más profundos se encontró una producción menor de gramíneas perennes y una mayor cobertura y densidad de mesquite que en los suelos someros, tanto al inicio (1995-1997) y al finalizar el periodo de estudio (2003-2005). El promedio de la producción de gramíneas perennes, de los cuatro potreros disminuyó un 83\% entre 1995-1997 y 2003-2005 debido a la sequía durante los últimos 5 años del estudio. No hubo diferencia ni entre la cobertura aérea del mezquite ni tampoco en la producción de las gramíneas perennes entre los tratamientos de la carga ligera y moderada al inicio o al final del estudio. No se produjo ningún cambio en la cobertura aérea del mezquite de 1995-1997 a 2003-2005 pero su densidad fue mayor en 2003-2005 comparada con la que se detectó en 1995-1997. Nuestro estudio presenta que tanto la profundidad del suelo como las fluctuaciones climáticas tienen un influencia mayor en la dinámica de la vegetación en áreas desérticas y semi-desérticas.

Key Words: brush control, drought, grazing, herbicides, rangeland

\section{INTRODUCTION}

Site factors such as topography, soil depth, soil texture, and precipitation play a critical role in determining the type of rangeland vegetation and its potential productivity (Holechek et al. 2004). Sound decisions on management practices such as brush control, seeding, and fertilization depend on understanding site potential.

Honey mesquite invasion and persistence of perennial grasses in the Chihuahuan Desert appears to be closely related to site characteristics such as soil depth and texture (Buffington and Herbel 1965; Herbel and Gibbens 1996; Molinar et al. 2002). However, experimental evaluation of these associations across large landscapes and long time periods is lacking. The

This research was supported by the New Mexico Agriculture Experimental Station, New Mexico State University, Las Cruces, NM 88003, USA, and was part of project 0172944.

Correspondence: Jerry Holechek, Dept of Animal and Range Sciences, 2980 S Espina St, MSC 31, New Mexico State University, Las Cruces, NM 88003, USA. Email: holechek@nmsu.edu

Manuscript received 30 May 2007; manuscript accepted 12 December 2007. objectives of this study were to evaluate the effects of soil depth on honey mesquite canopy cover and density and perennial grass standing crop. It was conducted over an 11-yr time period on two lightly stocked and two conservatively stocked pastures on the Chihuahuan Desert Rangeland Research Center in south-central New Mexico. The primary null hypothesis tested was that soil depth has no effect on honey mesquite cover and perennial grass standing crop. Our study tests the postulation by Noir-Meir (1973) and Holechek et al. (2004) that deep, sandy soils favor shrubs but shallow, sandy soils favor perennial grasses in desert and semiarid areas.

\section{MATERIALS AND METHODS}

\section{Study Area Description}

The study area was located on the New Mexico State University Chihuahuan Desert Rangeland Research Center (CDRRC; lat 
$32^{\circ} 32^{\prime} 30^{\prime \prime} \mathrm{N}$, long $\left.106^{\circ} 52^{\prime} 30^{\prime \prime} \mathrm{W}\right)$ operated by New Mexico State University, $37 \mathrm{~km}$ north of Las Cruces, New Mexico, in Dona Ana County. This flat to gently rolling area is in the southern portion of the Jornada del Muerto Plains between the San Andres Mountains to the east and the Rio Grande Valley to the west. The CDRRC covers an area of 25546 ha and elevation varies from $1330 \mathrm{~m}$ at the Rio Grande to $1945 \mathrm{~m}$ at the peak of Summerford Mountain. Soils of the CDRRC are fine loamy, mixed, thermic, typic haplargids of the Simona-Cruces association (Tembo 1990) underlain by calcium carbonate hardpan (caliche) at depths varying from a few centimeters to $1 \mathrm{~m}$ or more (Valentine 1970). In areas where the ground cover is sparse, sand dunes form around the invading honey mesquite (Prosopis glandulosa Torr.) plants (Wood 1969).

\section{Climate}

The climate on CDRRC is arid, with an average of $200 \mathrm{~d}$ in the frost-free period. The only permanent water sources are wells and pipelines provided for livestock use. Temperatures are high, with a mean maximum of $36^{\circ} \mathrm{C}$ during June, and a mean maximum of $13^{\circ} \mathrm{C}$ during January (Pieper and Herbel 1982). Temperature differences are substantial between day and night. Strong winds in the spring cause severe erosion and water-stress plants (Pieper and Herbel 1982).

Annual precipitation is bimodal. Summer precipitation (JulySeptember) is from localized convectional storms of high intensity but low frequency. Winter precipitation (DecemberFebruary) is relatively gentle and evenly distributed. Mean annual precipitation is $234 \mathrm{~mm}$, with $52 \%$ of the annual rainfall occurring during summer.

\section{Vegetation}

Primary grass species on our study area include black grama (Bouteloua eriopoda Torr.), dropseeds (Sporobolus spp.), threeawns (Aristida spp.), bush muhly (Mublenbergia porteri Kunth.), fluffgrass (Erioneuron pulchellum Tateoka), and tobosa (Hilaria mutica Buckley). The most commonly encountered shrub species is honey mesquite. It dominates the overstory and has been increasing over the past $100 \mathrm{yr}$ (Pieper and Herbel 1982). Other shrubs include broom snakeweed (Gutierrezia sarothrae Pursh), soap-tree yucca (Yucca elata av.), and creosotebush (Larrea tridentata [Pursh] Nutt.). Leatherweed croton (Croton pottsii Lam.) was the primary forb.

\section{Historical Background}

Four pastures with similar soils (sandy loams), topography (flat), and size were delineated and fenced in 1991 (Nelson et al. 1997; Winder et al. 2000). These include pasture 1 (1267 ha), pasture 2 (932 ha), pasture 3 (1219 ha), and pasture 4 (974 ha). The spatial ordering of the pastures from west to east is $1,2,3$, and 4 . These pastures have flat terrain and similar spacing of watering points. The only permanent water sources are wells and pipelines provided for livestock use. During 1992, 1993, and 1994, these pastures were used to study the effects of range condition and grazing intensity on cattle production (Winder et al. 2000) and wildlife populations (Nelson et al. 1997; Joseph et al. 2003).

In the autumn of 1995 and 1996 comprehensive range vegetation inventories of pastures $1,2,3$, and 4 were conducted to establish baseline vegetation data for future range research (Molinar 1999; Khumalo et al. 2007). This inventory characterized range sites and ecological condition through quantification of herbaceous standing crop, herbaceous basal cover and composition, and shrub canopy cover and density. It provided a basis for future evaluation of trends in vegetation productivity and ground cover in response to soil characteristics (depth and texture) and grazing treatments (light and conservative stocking).

\section{Description of Sampling Techniques}

Data collection was implemented in autumn (October, November) of 1996, 1996, 1997, 2003, 2004, and 2005. It involved quantification of forage perennial grass standing crop and honey mesquite cover and density on 10 permanent, evenly spaced key areas in each pasture (40 key areas total; Molinar 1999; Khumalo 2006). A 61-m line transect at each key area was used to sample perennial grass standing crop by clipping as described by Bonham (1989). Perennial grass standing crop was evaluated by off-setting the $61-\mathrm{m}$ line by $3.05 \mathrm{~m}$ and placing 10 $0.5-\mathrm{m}^{2}$ quadrats parallel to the first line at $6.1-\mathrm{m}$ intervals. Vegetation was clipped at ground level and hand-separated by species in the field. Only the current year's growth was quantified. Grass samples from clipped plots were oven-dried for $24 \mathrm{~h}$ at $55^{\circ} \mathrm{C}$.

Honey mesquite canopy cover on key areas was evaluated along the transects previously described by using the lineintercept method (Canfield 1941). Honey mesquite densities on key areas were determined by establishing belt transects. Three $40 \times 2 \mathrm{~m}$ belt transects were laid out perpendicular to the $61-\mathrm{m}$ line to estimate number of plants per hectare. The belt transects covered a measured area of $240 \mathrm{~m}^{2}$ on each of the 40 key areas.

Soil depth was determined by digging pits at each of the 40 key areas. Two range sites were encountered (shallow sandy and deep sandy). We considered the shallow sandy range key areas to be those having soils $\leq 40 \mathrm{~cm}$ in depth, and deep sandy range key areas were those having soil depth $>40 \mathrm{~cm}$. All four pastures had shallow $(10-40 \mathrm{~cm})$ and deep soils $(41-120 \mathrm{~cm})$. Soil depth and texture on each key area were relatively uniform, based on the data gathered by driving a steel measuring rod into the ground at various points and recording the depth to the caliche layer.

To study long-term vegetation trends from 1995 to 2005, data were pooled across the first 3 yr (1995-1997) and the last $3 \mathrm{yr}$ (2003-2005) of the study. In an analysis of grazing experiments, Holechek et al. (1999) found data pooled across the first and last $3 \mathrm{yr}$ of study gave the most meaningful comparisons of long-term vegetation changes. This particularly applies in areas where vegetation composition and forage production may not be equivalent across grazing treatments at study initiation and precipitation varies greatly among years.

\section{Stocking Rate and Grazing Intensity}

From January 1997 through late autumn 2001 we attempted to graze pastures 1 and 3 at a light (30\% use) intensity and pastures 2 and 4 at a conservative ( $40 \%$ use) intensity. Actual stocking levels assigned to light and conservative grazed treatments were, respectively, 124 and $63 \mathrm{ha} \cdot$ (animal unit per year [AUY]) ${ }^{-1}$ in 1997, 67 and $39 \mathrm{ha} \cdot \mathrm{AUY}^{-1}$ in 1998, 84 and $16 \mathrm{ha} \cdot \mathrm{AUY}^{-1}$ in 1999,112 and $24 \mathrm{ha} \cdot \mathrm{AUY}^{-1}$ in 2000, 
Table 1. Effect of soil depth on average autumn herbaceous standing crop $\left(\mathrm{kg} \cdot \mathrm{ha}^{-1}\right)$, honey mesquite canopy cover (\%), and honey mesquite density (plants $\cdot \mathrm{ha}^{-1}$ ) on lightly grazed (LG) and conservatively grazed (CG) rangelands for 1995-1997 and 2003-2005 on the Chihuahuan Desert Rangeland Research Center in south-central New Mexico. Sample size: $n=20$, that is, 20 transects per grazing treatment.

\begin{tabular}{|c|c|c|c|c|}
\hline \multirow[b]{2}{*}{ Species/group } & \multirow[b]{2}{*}{ Grazing level ${ }^{1}$ and soil depth ${ }^{2}$} & \multicolumn{2}{|c|}{ Autumn standing crop, cover, and density ${ }^{3}$} & \multirow[b]{2}{*}{$\mathrm{SE}^{4}$} \\
\hline & & $1995-1997$ & 2003-2005 & \\
\hline \multirow[t]{4}{*}{ Bouteloua eriopoda $\left(\mathrm{kg} \cdot \mathrm{ha}^{-1}\right)$} & LG - deep soil & $9 \mathrm{~B}$ & 2 & 33.5 \\
\hline & LG - shallow soil & $109 \mathrm{Aa}$ & $11 b$ & 30.3 \\
\hline & CG - deep soil ${ }^{3}$ & $12 \mathrm{~B}$ & 2 & 41.3 \\
\hline & CG - shallow soil & $137 \mathrm{Aa}$ & $34 \mathrm{~b}$ & 26.9 \\
\hline \multirow[t]{4}{*}{ Total perennial grasses $\left(\mathrm{kg} \cdot \mathrm{ha}^{-1}\right)$} & LG - deep soil & $53 \mathrm{Ba}$ & $7 \mathrm{~b}$ & 25.5 \\
\hline & LG - shallow soil & $231 \mathrm{Aa}$ & $27 \mathrm{~b}$ & 23.1 \\
\hline & CG - deep soil & $59 \mathrm{~B}$ & 16 & 31.5 \\
\hline & CG - shallow soil & $203 \mathrm{Aa}$ & $43 \mathrm{~b}$ & 20.5 \\
\hline \multirow[t]{4}{*}{ Mesquite canopy cover (\%) } & LG - deep soil & $9 \mathrm{~A}$ & $9 \mathrm{~A}$ & 0.87 \\
\hline & LG - shallow soil & $1 \mathrm{~B}$ & $3 \mathrm{~A}$ & 0.9 \\
\hline & CG - deep soil & $8 \mathrm{~A}$ & $6 \mathrm{~A}$ & 1.2 \\
\hline & CG - shallow soil & $1 \mathrm{~B}$ & $1 \mathrm{~B}$ & 0.8 \\
\hline \multirow[t]{4}{*}{ Mesquite density (plants $\cdot \mathrm{ha}^{-1}$ ) } & LG - deep soil & $698 \mathrm{Aa}$ & $777 \mathrm{Ab}$ & 44 \\
\hline & LG - shallow soil & $147 \mathrm{Ca}$ & $258 \mathrm{Bb}$ & 45.9 \\
\hline & CG - deep soil & $285 \mathrm{BCa}$ & $535 \mathrm{ABb}$ & 62.2 \\
\hline & CG - shallow soil & $208 \mathrm{BCa}$ & $375 \mathrm{Bb}$ & 40.7 \\
\hline
\end{tabular}

${ }^{1}$ LG indicates lightly grazed (29\% use of current forage production); CG, conservatively grazed (40\% use of current forage production).

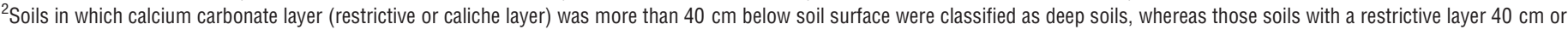
less below soil surface were classified as shallow soils.

${ }^{3}$ Data were pooled across the first 3 yr and the last 3 yr of study for trend comparisons as suggested by Holechek et al. (1999).

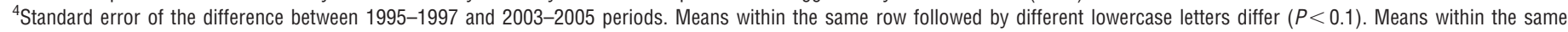
column followed by different uppercase letters differ $(P<0.1)$.

and 141 and $57 \mathrm{ha} \cdot \mathrm{AUY}^{-1}$ in 2001. All cattle were removed from the pastures in late November 2001 because of lack of forage from drought. Livestock grazing was discontinued on our study pastures in the 2002 through 2005 period because of drought and to allow better quantification of the two grazing treatments we applied in the 1997-2001 period. Detailed information on livestock management on the study pastures is provided by Thomas et al. (2007).

Grazing intensity on the four pastures was evaluated in early June of 1997, 1998, 1999, 2000, and 2001 using procedures of Holechek and Galt (2000). Percentage of use of perennial grasses was evaluated on four of the key areas evenly spaced within each pasture (Khumalo et al. 2007). Two 100-m transects were established each year for these evaluations. Percentage of use and residual vegetation were determined by clipping $10 \quad 0.5-\mathrm{m}^{2}$ quadrats at $10-\mathrm{m}$ intervals on a $100-\mathrm{m}$ transect for a total of 20 per key area. Grazing use of perennial grasses averaged $29 \%$ in lightly stocked and $40 \%$ on conservatively stocked pastures during the 1997-2001 study period (Khumalo et al. 2007).

\section{Statistical Analysis}

Effects of soil depth, time period, grazing treatment, and interactions for black grama standing crop, total perennial grass standing crop, mesquite canopy cover, and mesquite density were analyzed using a repeated measures analysis in PROC MIXED of SAS (version 9.1; SAS Institute, Inc.; Littell et al. 1996). Pastures (two per grazing treatment; $n=4$ ) were used as replications in these analyses. Relationships between mesquite cover, mesquite density, and perennial grass standing crop were evaluated using correlation and regression analyses in PROC REG of SAS (Freund and Littell 2000). The 40 key areas (10 per pasture) were used as observations in these analyses. Partial correlation and multivariate analyses (i.e., PROC GLM using the MANOVA statement) were also conducted with these data. The partial correlation involved the effects of the dependent variables. Significance was not detected with these correlation analyses; thus, results presented are from univariate analyses. A probability level of $10 \%$ was used in all statistical tests.

\section{RESULTS}

Honey mesquite cover and density tended to be higher $(P<0.1)$ on deep than on shallow soils across study period and stocking level (Table 1). In contrast, black grama and total perennial grass standing crops tended to be higher $(P<0.1)$ on shallow than on deep soils (Table 1). These relationships occurred at both the beginning (1995-1997) and ending (2003-2005) study periods.

Mesquite canopy cover was positively correlated $(P<0.1)$ with soil depth in both the 1995-1997 ( $r=0.71)$ and 2003$2005(r=0.60)$ periods. Mesquite density was also correlated $(P<0.1)$ with soil depth $(r=0.70,1995-1997 ; r=0.56,2003-$ 2005). In contrast, total perennial grass standing crop was negatively correlated $(P<0.1)$ with soil depth in both the 1995-1997 $(r=-0.66)$ and 2003-2005 ( $\mathrm{r}=-0.43)$ periods. Simple linear regression equations best described the relationship between mesquite canopy cover and soil depth (Fig. 1) whereas 


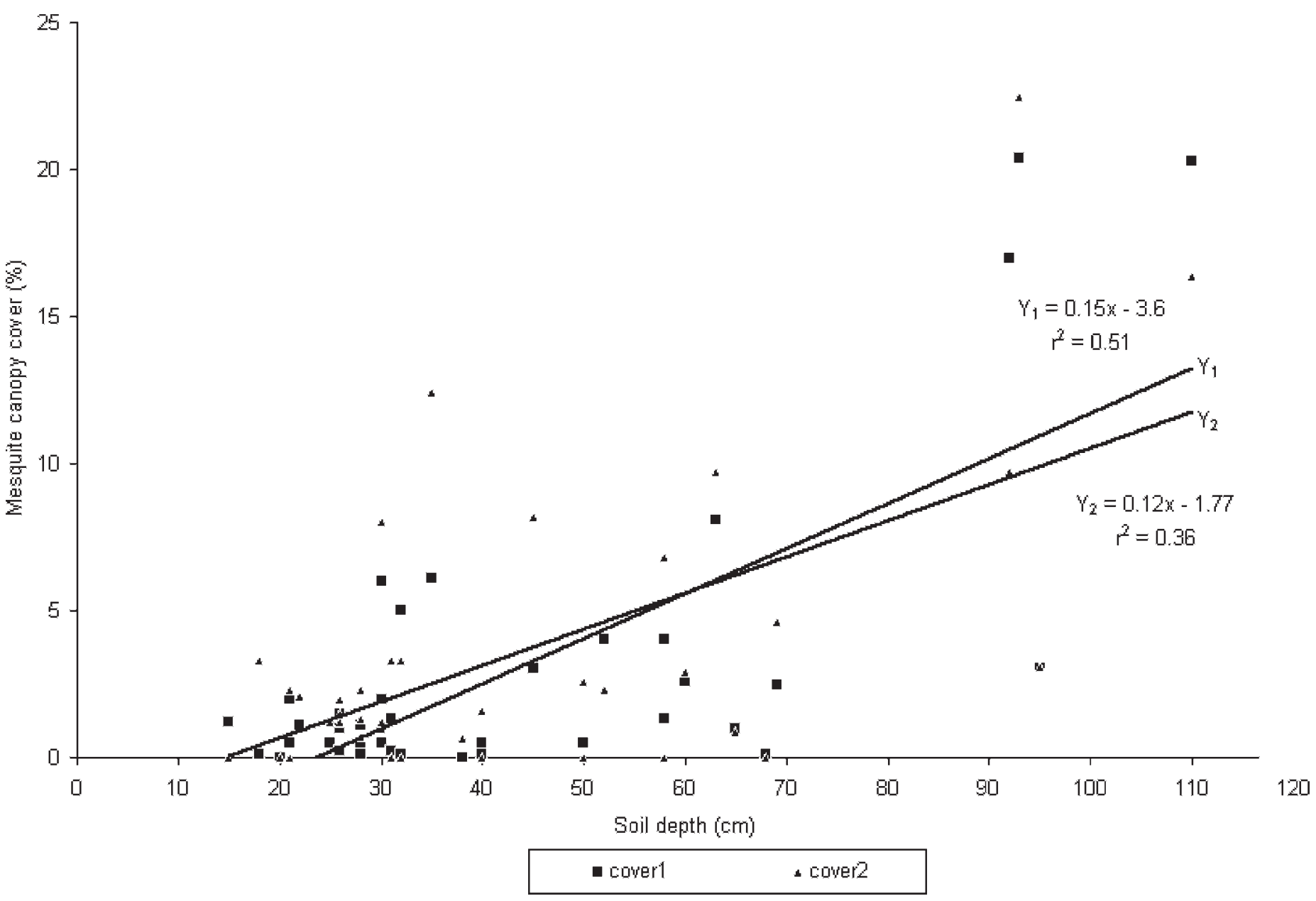

Figure 1. Relationship between honey mesquite canopy cover and soil depth on the Chihuahuan Desert Rangeland Research Center in south-central New Mexico, showing 1995-1997 and 2005 data. $Y_{1}$ is honey mesquite canopy cover from 1995-1997 pooled data; $Y_{2}$ is honey mesquite canopy cover from 2003-2005 pooled data. Cover1 is honey mesquite canopy cover from 1995-1997 pooled data; cover2 is honey mesquite canopy cover from 2003- 2005 pooled data.

curvilinear regression equations better described the relationship between perennial grass standing crop and soil depth (Fig. 2).

Weak negative correlations $(P<0.1)$ occurred between total perennial grass standing crop and mesquite cover $(r=-0.43$, 1995-1997; $r=-0.19,2003-2005)$. This also applied to the relationship between total perennial grass standing crop and mesquite density $(r=-0.45,1995-1997 ; r=-0.36,2003-$ 2005).

Total grasses and black grama standing crop were higher $(P<0.1)$ in 1995-1997 than in 2003-2005 (Table 1). There were $82 \%$ and $84 \%$ declines in perennial grass and black grama standing crops, respectively, from 1995-1997 to 20032005 for data pooled across soil depths and stocking levels. This decline was due to drought (Khumalo et al. 2007). Precipitation during the first $6 \mathrm{yr}$ of our study was slightly $(103 \%)$ above the long-term average but drought $173 \%$ and $65 \%$ of the long-term average total and growing season precipitation, respectively) occurred during the last $5 \mathrm{yr}$.

Honey mesquite canopy cover did not change $(P>0.1)$ from 1995-1997 to 2003-2005, but honey mesquite density was higher $(P<0.1)$ in 2003-2005 than in 1995-1997. The rate of increase was $50 \%$ and $78 \%$ on deep and shallow soils, respectively.
Black grama standing crop, total perennial grass standing crop, and honey mesquite cover did not differ $(P>0.1)$ between light and conservative grazing treatments for data pooled across soil depths and study periods (Table 1 ). They did not differ $(P>0.1)$ between light and conservative grazing treatments at either the beginning or end of the study. However, an interaction $(P<0.1)$ occurred between stocking level and study period for honey mesquite density. Between 1995-1997 and 2003-2005 there was an 84\% increase in honey mesquite density under conservative stocking compared to a $22 \%$ increase under light stocking.

\section{DISCUSSION}

It has been postulated that deep, coarse-textured soils facilitate water infiltration but have low moisture retention near the soil surface (Noy-Meir 1973; Holechek et al. 2004). Theoretically, this benefits shrub species (such as honey mesquite) having extensive, coarse root systems. In contrast, most moisture is retained near the soil surface by clay soils and sandy soils having a shallow, restrictive (caliche) layer. This should favor grasses with dense, short, fibrous root systems such as black 


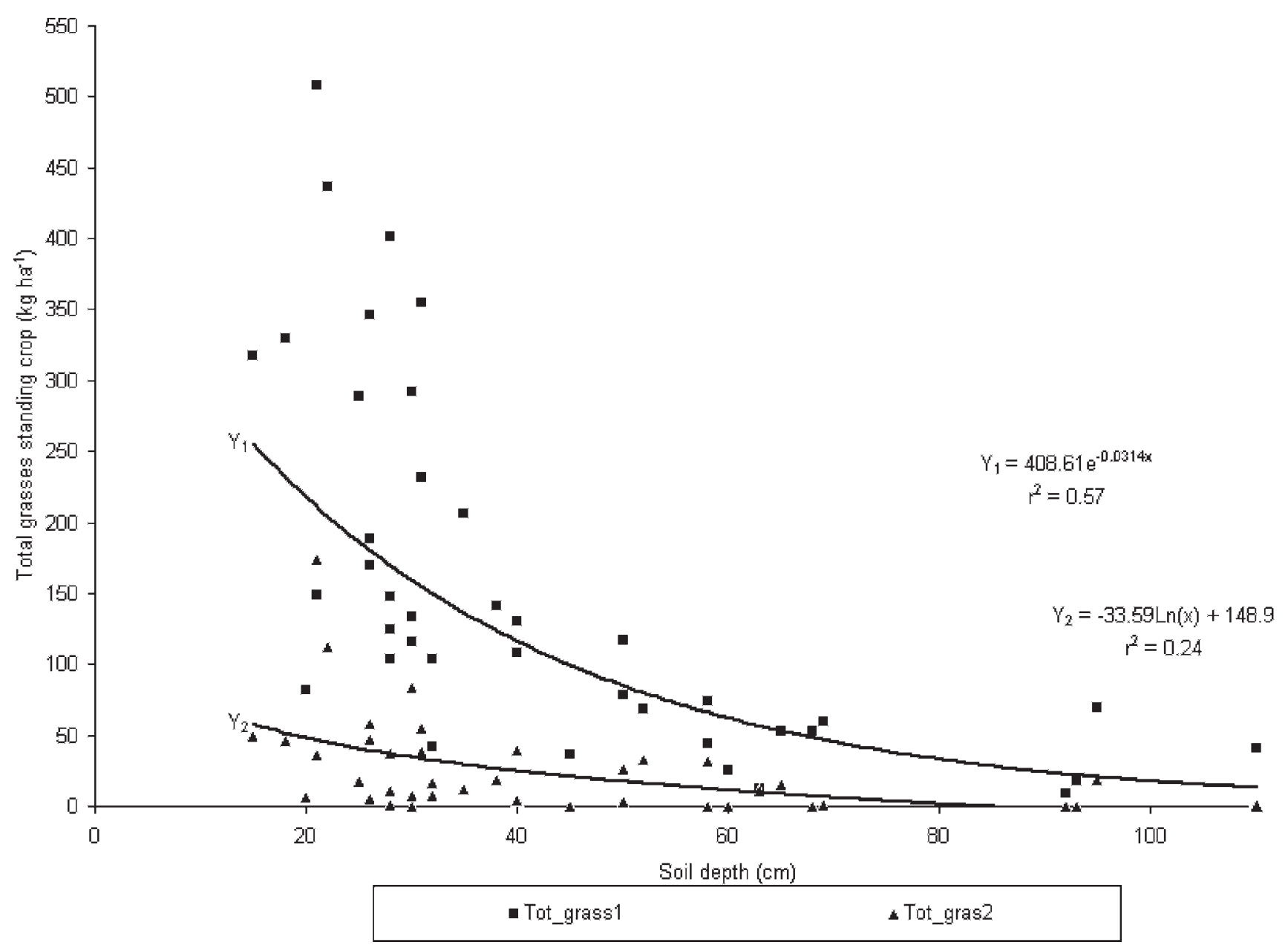

Figure 2. Relationship between soil depth and total perennial grass standing crop on the Chihuahuan Desert Rangeland Research Center in southcentral New Mexico, showing 1995-1997 and 2005 data. $Y_{1}$ is total grasses standing crop from 1995-1997 pooled data; $Y_{2}$ is total grasses standing crop from 2003-2005 pooled data.Tot_grass1 is total grasses standing crop from 1995-1997 pooled data; Tot_grass2 is total grasses standing crop from 2003-2005 pooled data.

grama. Our study conducted across a large landscape and extended time period provides strong experimental evidence confirming this postulation. Further supporting evidence is provided by Buffington and Herbel (1995) who found that honey mesquite abundance in the Chihuahuan Desert was higher on sandy than loamy-textured soils. Herbel and Gibbens (1996) found low black grama and perennial grass standing crops on deep sandy soils compared to loamy soils on the Jornada Experimental Range in south-central New Mexico. The most productive black grama stands occurred on shallow loamy or shallow sandy soils.

Honey mesquite densities showed a lower rate of increase under light grazing than under conservative grazing in our study. A detailed analysis of understory herbage and cover dynamics on light and conservative grazed pastures in our study pastures is provided by Khumalo et al. (2007). Perennial grass cover was better maintained under light grazing than under conservative grazing in the 1995-1997 through 2003-2005 period. This may have lowered the germination and survival of new honey mesquite plants. In north-central Texas, Scifres et al. (1974) reported moderately grazed pastures had lower honey mesquite canopy cover than those that were heavily grazed. In contrast, Brown and Archer (1999) found level of grass density and defoliation had no effect on honey mesquite emergence and survival on semiarid southern Texas rangeland. Their study indicated that honey mesquite invasion is minimally influenced by grass competition.

\section{MANAGEMENT IMPLICATIONS}

Our 11-yr study in the Chihuahuan Desert showed perennial grasses are favored by shallow sandy soils whereas honey mesquite is favored by deep sandy soils. Soil depth appears to largely explain why some parts of the Chihuahuan Desert are now dominated by honey mesquite while other areas remain as grasslands (Buffington and Herbel 1965; Gibbens et al. 1992; Navarro et al. 2002). Deep sandy soils with good remaining perennial grass cover are the sites most vulnerable to honey mesquite invasion from drought and heavy livestock grazing. Care should be taken to ensure these sites receive light to conservative livestock grazing. Burning and/or herbicidal control of honey mesquite may be necessary to prevent its invasion on deep sandy sites after extended droughts such as in the 1950s. Honey mesquite invasion does not appear to be a threat on most shallow sandy sites if sound grazing practices 
are applied (Navarro et al. 2002). Our study supports the postulation by Noy-Meir (1973) and Holechek et al. (2004) that deep, sandy soils favor shrubs but shallow, sandy soils favor perennial grasses in desert and semiarid areas.

\section{LITERATURE CITED}

Brown, J. R., AND S. ARChER. 1999. Shrub invasion of grassland: recruitment in continuous and not regulated by herbaceous biomass or density. Ecology 80:2385-2396.

Buffington, L. C., And C. H. Herbel. 1965. Vegetational changes in a semi-desert grassland from 1858 to 1963. Ecological Monographs 35:139-164.

Canfield, R. H. 1941. Application of the line intercept method in sampling range vegetation. Journal of Forestry 39:388-394.

Freund, R. J., and R. C. Littell. 2000. SAS System for regression. Cary, NC, USA: SAS Institute, Inc. $186 \mathrm{p}$.

Gibbens, R. P., R. F. Beck, R. P. McNeely, and C. H. Herbel. 1992. Recent rates of mesquite establishment in the northern Chihuahuan Desert. Journal of Range Management 45:585-588.

Herbel, C. H., and R. P. Gibbens. 1996. Post-drought vegetation dynamics on arid rangelands of New Mexico. Las Cruces, NM, USA: New Mexico Agricultural Experiment Station, Bulletin 776. 102 p.

HolecheK, J. L., and D. Galt. 2000. Grazing intensity guidelines. Rangelands $21: 11-14$.

Holechek, J. L., R. D. Pieper, and C. H. Herbel. 2004. Range management: principles and practices. 5th ed. Upper Saddle River, NJ, USA: Prentice-Hall Book Co. 607 p.

Holechek, J. L., M. Thomas, F. Molinar, and D. Galt. 1999. Stocking desert rangelands: what we've learned. Rangelands 21:8-12.

Joseph, J., M. Collins, J. Holechek, R. Valdez, and R. Steiner. 2003. Conservative and moderate grazing effects on Chihuahuan Desert wildlife sightings. Western North American Naturalist 63:43-49.

KHUMALo, G. Z. 2006. Long-term vegetation trends and productivity under conservative and light grazing on Chihuahuan Desert rangelands: application to Swaziland beef cattle production [dissertation]. Las Cruces, NM, USA: New Mexico State University. 125 p.

Khumalo, G., J. Holechek, M. Thomas, and F. Molinar. 2007. Long-term vegetation productivity and trend under two stocking levels on Chihuahuan Desert rangeland. Rangeland Ecology \& Management 60:165-171.
Littell, R. C., G. A. Milliken, W. W. Stroup, and R. D. Wolfinger. 1996. SAS system for mixed models. Cary, NC, USA: SAS Institute, Inc. 234 p.

Molinar, F. 1999. Effect of honey mesquite cover and soil depth on forage production in the Chihuahuan Desert [dissertation]. Las Cruces, NM, USA: New Mexico State University. $184 \mathrm{p}$.

Molinar, F., J. Holechek, D. Galt, and M. Thomas. 2002. Soil depth effects on Chihuahuan Desert vegetation. Western North America Naturalist 62:300-3006

Navarro, J. M., D. Galt, J. Holechek, J. McCormick, and F. Molinar. 2002. Long term impacts of livestock grazing on Chihuahuan Desert rangelands. Journal of Range Management 55:400-405.

Nelson, T., J. L. Holechek, R. Valdez, and M. Cardenas. 1997. Wildlife numbers on late- and mid-seral Chihuahuan Desert rangelands. Journal of Range Management 50:593-599.

Noy-MelR, I. 1973. Desert ecosystems: environment and producers. Annual Review of Ecology and Systematics 4:25-51.

Pieper, R. D., And C. H. HeRBel. 1982. Herbage dynamics and primary productivity of a desert grassland ecosystem. Las Cruces, NM, USA: New Mexico Agricultural Experimental Station Bulletin 695. 43 p.

SAS InstituTE, Inc. 1999. SAS/STAT user's guide, version 8. Cary, NC, USA: SAS Institute, Inc. 528 p.

Scifres, C. J., M. M. Kothmann, and G. W. Mathis. 1974. Range site and grazing system influence regrowth after spraying honey mesquite. Journal of Range Management 27:97-100.

TemBo, A. 1990. Influence of watering points and range condition on vegetation of the Chihuahuan Desert [dissertation]. Las Cruces, NM, USA: New Mexico State University. $127 \mathrm{p}$.

Thomas, M. G., J. Hawkes, G. Khumalo, and J. L. Holechek. 2007. Brangus cow-calf performance under two stocking levels on Chihuahuan Desert rangeland. Rangeland Ecology \& Management 60:110-114.

ValentinE, K. A. 1970. Influence of grazing intensity on improvement of deteriorated black grama range. Las Cruces, NM, USA: New Mexico Agricultural Experimental Station Bulletin 553. 659 p.

Winder, J. A., C. C. Balley, M. G. Thomas, and J. L. Holechek. 2000. Breed and stocking rate effects on Chihuahuan Desert cattle production. Journal of Range Management 53:32-39.

Wood, J. E. 1969. Rodent populations and their impact on desert rangelands. Las Cruces, NM, USA: New Mexico Agricultural Experimental Station Bulletin 555. $17 \mathrm{p}$. 